\title{
Gold Mine Wastewater Induced Morpho-physiological Alteration of Four Biodiesel Producing Species
}

\author{
Hamim '", Lutfiani', Deden Saprudin², Putri Nur Azizah Hutagalung', Hadisunarso', Luluk Setyaningsih³, Hirmas Fuady \\ Putra $^{1}$ \\ ${ }^{1}$ Department of Biology, Faculty of Mathematics and Natural Sciences, Bogor Agricultural University, Kampus IPB Darmaga, Bogor, \\ Indonesia \\ ${ }^{2}$ Department of Chemistry, Faculty of Mathematics and Natural Sciences, Bogor Agricultural University, Kampus IPB Darmaga, Bogor, \\ Indonesia \\ ${ }^{3}$ Faculty of Forestry, University of Nusa Bangsa, Tanasareal, Bogor, Indonesia
}

\section{ARTICLE INFO}

Article history:

Received December 15, 2019

Received in revised form November 17, 2020

Accepted November 20, 2020

\section{KEYWORDS:}

biodiesel feedstock,

cyanide,

gold mine wastewater,

non-edible oil,

phytoremediation

\begin{abstract}
This experiment aimed to determine the adaptability of four biodiesel-producing plants to gold mine wastewater based on morpho-physiological properties. Four species namely jatropha (Jatropha curcas), castor bean (Ricinus communis), wild candlenut (Reutealis trisperma) and bead tree (Melia azedarach) were grown in water culture using Hoagland solution for 2 weeks and then treated with gold mining wastewater at $0 \%$ (control), $25 \%, 50 \%$, and $75 \%$ (v/v) for 3 weeks. Growth, anatomical and physiological characteristics were observed during the treatment. The results showed that gold mine wastewater significantly decreased growth of the four species despite varied among the species. Wastewater had significant effect on leaves anatomy of Jatropha but not on others. It also significantly induced the increase of malondialdehyde (MDA) content in Jatropha and castor bean, but not in wild candlenut and bead-tree. Meanwhile, the treatment significantly decreased chlorophyll content of all species with the most in bead-tree plant, and leaves relative water content (RWC) particularly in castor bean and bead-tree plants. There was strong negative correlation between the increase of MDA content and the decrease of chlorophyll content and leaf RWC. Among the four species, wild candlenut ( $R$. trisperma) was the most resistant to gold mine wastewater based on morphological and physiological properties.
\end{abstract}

\section{Introduction}

Gold is one of the important commodities in the world economy which has triggered the growth of gold ore mining activities, both on large industrial scale as well as small artisanal/community scale. Gold has been used as a parameter of prosperity for a society, but many problems have been arising related to gold mining activities particularly the problem of environmental contamination (Krisnayanti and Anderson 2014). Gold mining activities often result in severe environmental pollution due to the use of chemical compounds for gold extractions such as cyanide $(\mathrm{CN})$ as well as the accumulation of heavy metals such as lead and mercury (Hidayati et al. 2009; Rodríguez et al. 2009; Setyaningsih et al. 2018b).

\footnotetext{
* Corresponding Author

E-mail Address: hamim@ipb.ac.id
}

The toxic effects of gold mining wastewater due to higher content of cyanide on morphology, anatomy and physiology of Reutelis trisperma have been demonstrated by Hamim et al. (2017a). According to Towill et al. (1978) cyanide as an irreversible inhibitor of cytochrome-c-oxidase enzymes in the fourth complex of the mitochondrial membrane will be bound to iron which is a cofactor of proteins. This cyanide bond to the cytochrome enzyme will prevent electron transport from cytochrome-coxidase to oxygen, so that the electron transport chain is disrupted and these cells cannot produce ATP aerobically for their energy needs. In addition, at higher doses, the uptake of this substance is faster than metabolism so cyanide accumulation occurs in plant tissues and causes toxicity to plants (Larsen et al. 2005). Therefore, some efforts to reduce environmental pollution that may occurred due to cyanide contaminant need to be made. 
Environmental pollution caused by the use of cyanide as well as other hazardous substances can be minimized by an innovative, economical and environmentally friendly technologies known as phytoremediation. The principle technology of phytoremediation is a process to reduce contaminants mediated by plants, including trees, grasses and aquatic plants by destruction, inactivation or immobilization of contaminants into non-hazardous forms (Chaney et al. 1995; Sarwar et al. 2017), which sometimes also involving some beneficial microbes (Feng et al. 2017). Moreover, phytoremediation has also been proposed as important method to reduce environmental cyanide pollution (O'Leary et al. 2014), because some plants have capability to detoxify cyanide and assimilating exogenous cyanide (Ebbs et al. 2004).

The ability of plants to survive in polluted environments can be used as a basic indication of plant capacity as phytoremediation agents (Setyaningsih et al. 2018a). Jatropha (Jatropha curcas), castor bean (Ricinus communis), wild candlenut (Reutealis trisperma) and bead-tree (Melia azedarach) are non-edible oil producing plants that has been confirmed to be able to grow on contaminated soil (Romeiro et al. 2006; Khamis et al. 2014; Pranowo et al. 2015; Hilmi et al. 2018). Utilisation of those plant in phytoremediation program may have several benefits because in addition to their capacity to reduce contaminant from the soil, these plant also produce non-edible oil which provide economic benefit to the community. Meanwhile, the capacity of those plants to grow under higher contaminated media especially with high cyanide content such as gold mine wastewater need to be observed.

This study aimed to analyse morphological, anatomical, and physiological responses of jatropha, castor bean, wild candlenut and bead-tree plants to gold mine wastewater.

\section{Materials and Methods}

This research was carried out from May-September 2018 at the Green House as well as Laboratory of Plant Physiology, Department of Biology, Faculty of Mathematics and Natural Sciences, Bogor Agricultural University, Kampus IPB Dramaga, Bogor, Indonesia, 16680. Plant materials that were used in this experiment were provided by the Research
Centre for Industrial and Beverage Crops (Balittri), Pakuwon, Sukabumi, West Java, Indonesia.

\subsection{Procedures}

The experiment was carried out using a completely randomized design with two factors. The first factor was four non-edible oil producing species, namely: jatropha (Jatropha curcas), castor bean (Ricinus communis), wild candlenut (Reutealis trisperma), and bead-tree (Melia azedarch). The second factor was water-culture media treatment using gold mine wastewater with different gold mine wastewater concentrations consisted of $0.25 \%, 50.0 \%$ and $75.0 \%$.

Five-month-old plants grown in the pots were removed slowly from their pots and then the root was cleaned from the soil by soaking the root in the water. The plants then were grown in the 81 water culture box $\left(40 \times 35 \times 20 \mathrm{~cm}^{3}\right)$ contained half strength of Hoagland solution with the composition based on Epstein (1972), and the plants acclimatized for 3 weeks. Each box contained 4 plants with aerator was installed in the middle of the box to supply oxygen. To support the plants to stand in water culture, each box was equipped by Styrofoam. After 3 weeks, the water culture medium was replaced with new solution contained half strength of Hoagland solution which was treated with four concentrations of wastewater: $0 \%$ (control), 25\%, 50\%, and 75\%. Each treatment was carried out three times. To analyse the response of four species, the wastewater treatment was given for 21 days.

\subsection{Morphological Parameters}

Morphological parameters observed were plant height, leaf number, leaf area, and shoots and roots dry weight after 21 days of the treatment. Fully expanded leaves from all the species were scanned using scanner and the leaf area was analysed using the Image application. Shoot and roots dry weight was measured after the biomass was dried using oven for 3 days at $80^{\circ} \mathrm{C}$. Morphological changes were observed during the experiment by notifying the changes that occurred in the plants such as wilting, yellowing or leaves necrosis.

\subsection{Leaf Anatomical Parameters}

Leaf anatomical analysis were carried out to the control plants and the plant treated with the highest concentration of wastewater which still alive after 
21 days of the treatment by making transverse slices using a razor blade (free hand section method). Parameters observed were the thickness of leaves, upper epidermis, palisade tissue, spongy tissue, and lower epidermis. Each leaf incision was observed 5 times or at five field of view. The observations were made using Olympus CX-21 microscope with $40 \times 10$ magnification. Photo preparations are taken using Optilab Viewer v.2.1. The measurement of anatomical parameters was calculated using ImageJ software (NIH, USA).

\subsection{Physiological Parameters}

\subsubsection{Leaf Chlorophyll Content Analysis}

Chlorophyll content analysis was carried out to understand the physiological response of the plants to gold mine wastewater. Photosynthetic pigment analysis was carried out based on Quinet et al. (2012). A $0.1 \mathrm{mg}$ of leaf sample was ground using $80 \%$ of acetone and then was filtered with Whatman paper. The absorbance of the extract was measured by spectrophotometer (Gysys 20 Thermo Spectronic) at the wavelength $(\lambda)$ of $470 \mathrm{~nm}, 646 \mathrm{~nm}$, and 663 $\mathrm{nm}$. The leaf chlorophyll content was calculated by Lichtenthaler's equation as follow (Lichtenthaler 1987):

$\underset{(\mu \mathrm{g} / \mathrm{g} \text { fresh weight })}{\text { Total chlorophyll }}=(7.15 \times \mathrm{A663})+(18.71 \times \mathrm{A}$ A646 $)$

$\begin{aligned} & \text { Chlorophyll a } \\ & (\mu \mathrm{g} / \mathrm{g} \text { fresh weight })\end{aligned}=(12.25 \times \mathrm{A663})-(2.79 \times \mathrm{A} 646)$

Chlorophyll b

$(\mu \mathrm{g} / \mathrm{g}$ fresh weight $)=(21.5 \times \mathrm{A} 646)-(5.1 \times \mathrm{A} 663)$

\subsubsection{Lipid Peroxidation Analysis}

Quantitative analysis of the level of lipid peroxidation was carried out by measuring the content of Malondialdehyde (MDA) which is the end result of lipid peroxidation by following the method developed by Hodges et al. (1999) with some modifications. MDA levels were determined by spectrophotometer at a wavelength of $450 \mathrm{~nm}, 532$ $\mathrm{nm}, 600 \mathrm{~nm}$, and calculated using the formula:

$\begin{aligned} & {[\mathrm{MDA}](\mu \mathrm{mol} / \mathrm{g}} \\ & \text { fresh weight })\end{aligned}=6.45 \times(\mathrm{D} 532-\mathrm{D} 600)-0.56 \times \mathrm{D} 450$

\subsubsection{Relative Leaf Water Content Analysis}

The measurement of relative water content (RWC) of leaves was carried out followed the method of Barr and Weatherley (1962). The percentage of RWC was calculated using the formula:

$$
\text { RWC }(\%)=\frac{\text { Fresh weight }- \text { dry weight }}{\text { Turgud weight }- \text { dry weight }} \times 100
$$

\subsection{Data Analysis}

Observation data were analyzed using one way ANOVA at 95\% confidence level using SPSS 16.0 software. Further tests between treatments and their interactions were carried out using Duncan Multiple Range Test (DMRT) at $\alpha=0.05$. The regression between parameters was also analysed to understand the correlation between the parameters.

\section{Results}

\subsection{Chemical Analysis of Wastewater}

Chemical analysis of wastewater from gold mines showed that the wastewater contained very high cyanide, which was $34.6 \mathrm{mg} / \mathrm{l}$ with medium level of $\mathrm{Na}$ and $\mathrm{K}$, while the other compounds include heavy metals such as $\mathrm{Pb}, \mathrm{Cd}$ and $\mathrm{Hg}$ were very low (Table 1 ). The high content of cyanide was because wastewater used in the experiment was collected directly from gold mine industry that had not been treated. According to the regulation of Indonesian Ministry of Environment, the maximum limit of cyanide content in liquid waste that is allowed to be dispersed to the environment must be less than $0.5 \mathrm{mg} / \mathrm{l}$, because cyanide is very toxic which for plants it can inhibit plant growth and decrease crop productivity.

\subsection{Morphological Parameters}

The treatment with gold mine wastewater with various concentrations for 21 days affected the growth of all species. At the second week all the plants were still able to grow well. However, after two weeks the plants at highest gold mine wastewater concentration (75\%) began to experience morphological changes, such as wilting, yellowing, and some plants were even dead.

\subsubsection{The Increase of Plant Height}

Based on statistical analysis, plant species and wastewater concentrations were significantly $(p<0.05)$ affected the increase of plant height, especially for castor bean and bead-tree, while for jatropha and wild candlenut they did not. The higher concentration of gold mine wastewater caused lower 
values of height increase (Table 2). Jatropha and wild candlenut plants were still experiencing the increase of plant height even though they got wastewater treatment up to $75 \%$. Castor bean only experienced high growth at the concentrations of $0 \%, 25 \%$ and $50 \%$, and did not grow any more at the concentration of $75 \%$, while bead-tree plants was not able to grow at the concentrations of $50 \%$ and $75 \%$, and even the plants were dead at the concentration of $75 \%$ gold mine wastewater (Table 2 ).

\subsubsection{The Increase of Leaf Number (ILN)}

The concentration of gold mine wastewater and plant species significantly $(p<0.05)$ affected the increase of leaf number (ILN) in plants during the treatment. Gold mine wastewater decreased leaf number represented by ILN value (Table 3 ). Plants without gold mine wastewater $(0 \%)$ experienced a large increase in leaves number, while plants treated with gold mine wastewater experienced a significant decreased $(p<0.05)$ in ILN values. Among the four species, castor bean had the lowest, while bead-tree had the highest ILN value at the control treatment. At high wastewater concentrations, castor bean and bead-tree plants did not increase the number of leaves at all during 21 days of treatment, while wild candlenut still had relatively high ILN value (Table 3 ). Jatropha leaf was still grown even though the ILN value was significantly decrease due to gold mine wastewater treatment.

\subsubsection{The Increase of Leaves Area (ILA)}

Gold mine wastewater treatment also decreased leaf area all the species significantly $(\mathrm{p}<0.05)$. There was significant interaction $(\mathrm{p}<0.05)$ between plant species and the treatment of gold mine wastewater to the increase of leaf area (ILA) of the plants (Table 4). The concentration of gold mine wastewater significantly $(\mathrm{p}<0.05)$ decreased ILA values (Table 4). The largest decrease of ILA was found in the castor bean and beadtree plants subjected to $75 \%$ of gold mine wastewater, while the smallest was found in wild candlenut(Table 4).

Table 1. The content of macro- and micronutrient, cyanide (CN) and heavy metals from gold mine wastewater

\begin{tabular}{lccr}
\hline Component & Content $(\mathrm{ppm})$ & Component & Content $(\mathrm{ppm})$ \\
\hline $\mathrm{Na}$ & 117.320 & $\mathrm{~B}$ & $<0.02$ \\
$\mathrm{~K}$ & 34.824 & $\mathrm{CN}$ & 34.595 \\
$\mathrm{Ca}$ & 1.743 & $\mathrm{Ni}$ & 0.039 \\
$\mathrm{Mg}$ & 1.194 & $\mathrm{Co}$ & $<0.005$ \\
$\mathrm{Fe}$ & 2.313 & $\mathrm{~Pb}$ & $<0.004$ \\
$\mathrm{Cu}$ & 6.788 & $\mathrm{Cd}$ & $<0.005$ \\
$\mathrm{Zn}$ & 0.319 & $\mathrm{Ag}$ & 0.025 \\
$\mathrm{Mn}$ & 0.087 & $\mathrm{Hg}$ & 0.004 \\
$\mathrm{Mo}$ & $<0.005$ & & \\
\hline
\end{tabular}

Table 2. The increase of plant height of four species subjected to different treatment of gold mining wastewater for 21 days Plants Gold mine wastewater treatment $(\%)$

\begin{tabular}{|c|c|c|c|c|}
\hline & $0 \%$ & $25 \%$ & $50 \%$ & $75 \%$ \\
\hline & \multicolumn{4}{|c|}{ 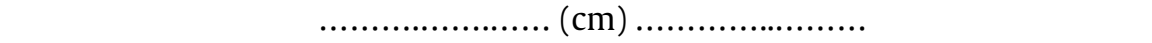 } \\
\hline atropha & $4.00^{\mathrm{b}}$ & $2.58^{\mathrm{c}}$ & $2.00^{\text {cd }}$ & $1.11^{\mathrm{e}}$ \\
\hline Castor bean & $1.25^{\mathrm{de}}$ & $0.25^{\mathrm{ef}}$ & $0.17^{\text {ef }}$ & $0.00^{\mathrm{f}}$ \\
\hline Wild candlenut & $2.29^{c}$ & $1.74^{\text {cd }}$ & $1.49^{\mathrm{d}}$ & $1.33^{\text {de }}$ \\
\hline Bead-tree & $8.47^{\mathrm{a}}$ & $3.19^{\mathrm{bc}}$ & $0.00^{\mathrm{f}}$ & $0.00^{\mathrm{f}}$ \\
\hline
\end{tabular}

The numbers followed by the same letters are not significantly different based on the DMRT test with the $\alpha$ level of 5\%

Table 3. The increase of leaf number (ILN) of four species subjected to different concentration of gold mine wastewater treatment for 21 days

\begin{tabular}{lcccc}
\hline Plant species & \multicolumn{5}{c}{ Gold mine wastewater treatment $(\%)$} \\
\cline { 2 - 5 } & $0 \%$ & $25 \%$ & $50 \%$ & $75 \%$ \\
\hline Jatropha & $2.67^{\mathrm{ab}}$ & $1.50^{\mathrm{cd}}$ & $1.08^{\mathrm{cde}}$ & $0.58^{\mathrm{def}}$ \\
Castor bean & $0.67^{\mathrm{def}}$ & $0.17^{\mathrm{ef}}$ & $0.08^{\mathrm{ef}}$ & $0.00^{\mathrm{f}}$ \\
Wild candlenut & $2.08^{\mathrm{abc}}$ & $1.83^{\mathrm{bc}}$ & $1,69^{\mathrm{bc}}$ & $1.56^{\mathrm{cd}}$ \\
Bead-tree & $2.89^{\mathrm{a}}$ & $2.08^{\mathrm{ac}}$ & $0.00^{\mathrm{f}}$ & $0.00^{\mathrm{f}}$ \\
\hline
\end{tabular}

The numbers followed by the same letters are not significantly different based on the DMRT test with the $\alpha$ level of $5 \%$ 


\subsubsection{Plant Dry Weight}

Not only plant height and leaves area, gold mine wastewater had a significant effect on plant growth which was characterized by the decrease of shoot and roots dry weight (Figure 1). A significant decrease in canopy dry weight $(p<0.05)$ was shown in Jatropha and bead-tree plants treated by gold mine wastewater, but not in castor bean and wild candlenut plants (Figure 1a). The largest decrease in canopy dry weight occurred in bead-tree plants (82.6\%), followed by jatropha (51.6\%), while castor bean and wild candlenut plants only experienced a slight decrease in canopy dry weight, which was approximately by 16.8 and $21.5 \%$ respectively.

Treatment of gold mine wastewater also caused a significant reduction $(\mathrm{p}<0.05)$ in the dry weight of root biomass in all plants, except for wild candlenut (Figure $1 \mathrm{~b})$. The negative response of plants to the treatment of gold mine wastewater occurred in bead-tree plants which experienced a decrease in root dry weight up to $72.4 \%$ at $75 \%$ treatment, followed by castor bean which decreased up to $57.9 \%$ and jatropha (47.3\%), while wild candlenut did not experience a significant decrease in dry weight of the root, which was only decreased by about $26 \%$. For jatropha, and bead-tree plant, the decrease of both canopy and roots due to the treatment of gold mine wastewater occurred even at the treatment with a lower concentration (25\%). This shows that gold mine wastewater had a negative effect on almost all plants except wild candlenut.

\subsection{Leaves Anatomy Analysis}

The treatment of gold mine wastewater did not only affect the morphological characters of the four species, but also affected the anatomical structure of the plants. Anatomical observations showed that plants treated with gold mine wastewater underwent significant $(p<0.05)$ changes in some leaf anatomy parameters which varied among the apecies (Table 5). Observations were made only at concentrations of $0 \%$ and $50 \%$, because some plants grown at the concentration of $75 \%$ died since 17 days after treatment.

The treatment with gold mine wastewater caused a significant $(p<0.05)$ decrease in the thickness of the leaves, upper epidermis, palisade tissue, spongy tissue, and lower epidermis of jatropha plant compared to the conditions without wastewater. Meanwhile, although there was a slight decline of those tissues in the other three species, the decline was not significantly different (Table 5 ). In castor bean, gold mine wastewater treatment slightly increased the thickness of palisade and spongy tissue, although the increase was not significantly different from control plants (Table 5).

Table 4. The increase of leaf area (ILA) of four plant species under control conditions and gold mine wastewater treatments for 21 days

\begin{tabular}{|c|c|c|c|c|}
\hline \multirow[t]{2}{*}{ Plant species } & \multicolumn{4}{|c|}{ Gold mine wastewater treatment (\%) } \\
\hline & $0 \%$ & $25 \%$ & $50 \%$ & $75 \%$ \\
\hline Jatropha & $155.76^{\mathrm{a}}$ & $95.20^{\mathrm{b}}$ & $87.22^{\mathrm{b}}$ & $59.42^{c}$ \\
\hline Castor bean & $46.21^{\mathrm{c}}$ & $4.83^{\mathrm{efg}}$ & $0.00^{\mathrm{g}}$ & $0.00^{\mathrm{g}}$ \\
\hline Wild candlenut & $42.21^{\mathrm{cd}}$ & 25.49 de & $22.71^{\text {def }}$ & $21.09^{\text {efg }}$ \\
\hline Bead tree & $3.45^{\mathrm{fg}}$ & $0.36^{\mathrm{g}}$ & $0.00^{\mathrm{g}}$ & $0.00^{\mathrm{g}}$ \\
\hline
\end{tabular}

The numbers followed by the same letters are not significantly different based on the DMRT test with the $\alpha$ level of 5\%
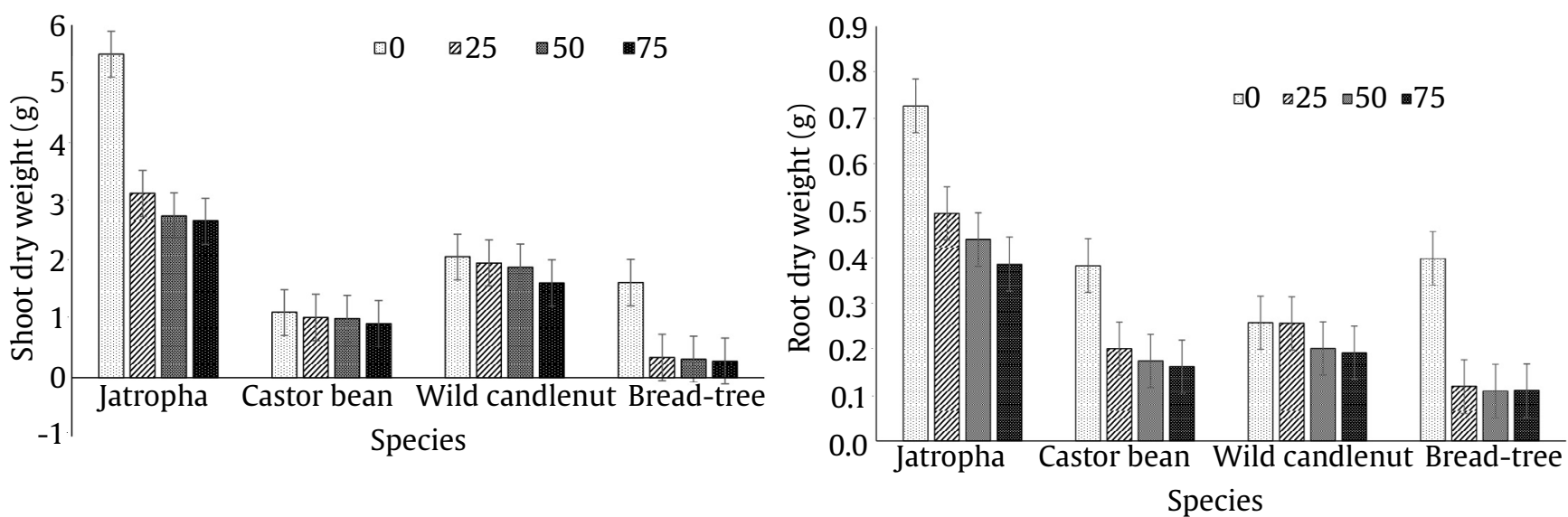

Figure 1 . The average dry weight of the shoot and the root of four species obtained with gold mine wastewater at $0 \%, 25 \%$, $50 \%$, and $75 \%$ treatment in water culture 


\subsection{Physiological Parameters}

\subsubsection{Lipid Peroxidase Analysis}

Malondialdehyde (MDA) is a product of lipid peroxidation process that occurs when plants experience stress. The increase of gold mine wastewater concentration caused a significant $(\mathrm{p}<0.05)$ increase in leaf MDA content in two plant species (jatropha and castor bean), but it was not significant in wild candlenut and bead-tree although it tended to increase slightly due to the treatment of gold mine wastewater (Figure 2a). Based on the data obtained in Figure 3, there was an interaction between plant species with the concentration of gold mine wastewater which influenced MDA content. The higher the concentration of wastewater, the more MDA content we found. Test data showed that the increase of MDA levels in Jatropha plant was approximately $31 \%$ and in castor bean was $45 \%$ if treated by gold mine wastewater of $75 \%$. Jatropha and castor bean had higher MDA content than wild candlenut and bead-tree plants (Figure 2).
The lowest average of leaf MDA content was obtained in bead-tree plants, while the highest was found in jatropha.

In contrast to the leaves, the treatment of gold mine wastewater did not cause an increase in root MDA content of the four species, although there was a tendency to increase due to the increase of wastewater concentration (Figure 2b). The lowest average MDA root formation was found in wild candlenut plant and the highest was in the castor bean plant (Figure $2 \mathrm{~b}$ ).

\subsubsection{Chlorophyll Content Analysis}

In contrast with MDA content, the treatment of gold mine wastewater had a significant effect on the decrease of chlorophyll content. Plants treated with high concentrations of gold mine wastewater had the lowest total chlorophyll content. The highest chlorophyll content of control plants as well as treated plants was found in wild candlenut plants, while bead-

Table 5. Anatomical structure of for species leaves after 21 days of gold mine wastewater treatment

\begin{tabular}{|c|c|c|c|c|c|}
\hline \multirow[t]{2}{*}{ Thickness ( $\mu \mathrm{m})$} & \multirow[t]{2}{*}{ Treatments (\%) } & \multicolumn{4}{|c|}{ Plant species } \\
\hline & & Jatropha & Castor bean & Wild candlenut & Bread-tree \\
\hline Upper & 0 & $9.43^{a}$ & $6.90^{\mathrm{b}}$ & $5.24^{c}$ & $4.99^{\mathrm{cd}}$ \\
\hline Epidermis & 50 & $7.48^{\mathrm{b}}$ & $6.94^{\mathrm{b}}$ & $5.05^{\mathrm{cd}}$ & $3.87^{d}$ \\
\hline Palisade & 0 & $20.79^{a}$ & $17.55^{\mathrm{b}}$ & $11.12^{\text {cd }}$ & $13.84^{c}$ \\
\hline tissues & 50 & $11.38^{\mathrm{cd}}$ & $19.38^{\mathrm{ab}}$ & $10.40^{\mathrm{d}}$ & $9.49^{\mathrm{d}}$ \\
\hline Sponge & 0 & $33.21^{\mathrm{a}}$ & $23.23^{\mathrm{b}}$ & $11.97^{c}$ & $14.87^{c}$ \\
\hline tissues & 50 & $30.40^{\mathrm{a}}$ & $25.85^{b}$ & $11.55^{\mathrm{c}}$ & $12.32^{\mathrm{c}}$ \\
\hline Lower & 0 & $7.83^{a}$ & $7.74^{\mathrm{ab}}$ & $4.07^{c}$ & $4.14^{c}$ \\
\hline epidermis & 50 & $6.21^{\mathrm{b}}$ & $6.41^{\mathrm{ab}}$ & $3.67^{c}$ & $3.96^{c}$ \\
\hline Leaves & 0 & $74.17 a$ & $53.11^{b}$ & $33.48^{\mathrm{de}}$ & $39.63^{\text {cd }}$ \\
\hline thickness & 50 & $48.58^{\mathrm{bc}}$ & $52.50^{\mathrm{b}}$ & $32.59^{d e}$ & $32.46^{\mathrm{de}}$ \\
\hline
\end{tabular}

The numbers followed by the same letters are not significantly different based on the DMRT test with the $\alpha$ level of $5 \%$
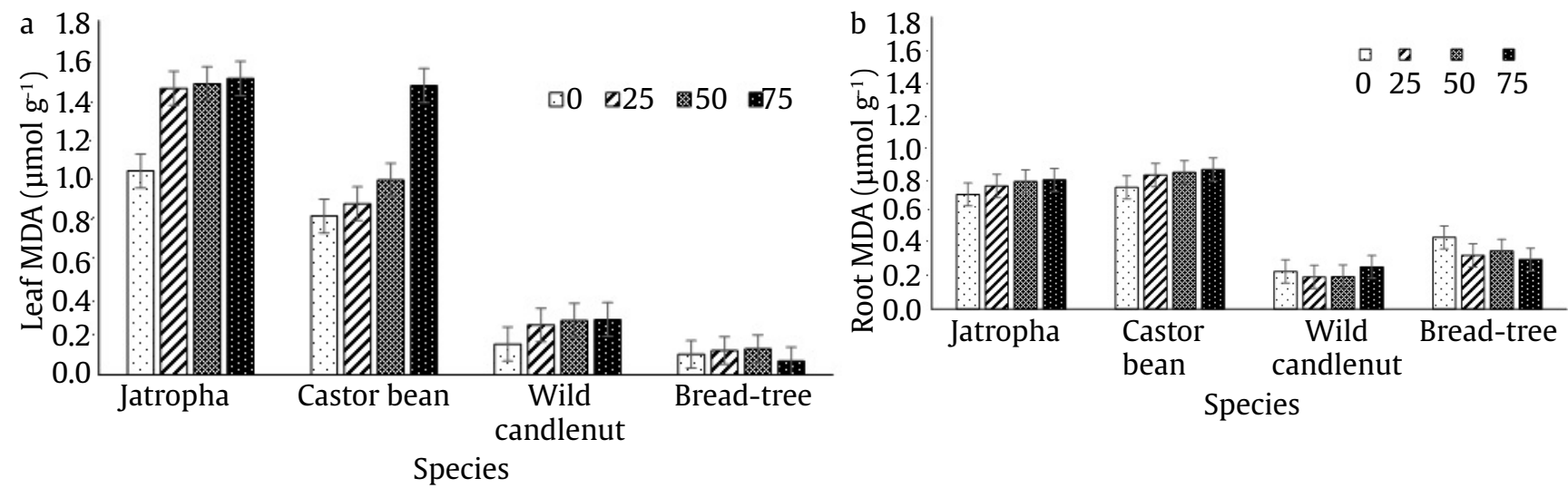

Figure 2. The average content of MDA in the leaf (a) and root (b) of the four plant species on liquid waste treatment of gold mines $0 \%, 25 \%, 50 \%$, and $75 \%$ 
tree plants had the lowest chlorophyll content under highest gold mine wastewater treatment (Figure 3). Total chlorophyll content of leaves in $75 \%$ treatment decreased from $24-79 \%$ with the smallest decrease in Jatropha plant and the biggest decrease in beadtree plants. The decrease in total chlorophyll content significantly occurred in plants that received $50 \%$ or more wastewater treatment, even though in castor bean and wild candlenut plants, the decrease in chlorophyll was shown in plants that received $25 \%$ of gold mine wastewater (Figure 3).

\subsubsection{Relative Water Content (RWC) Analysis}

The measurement of leaf relative water content (RWC) was carried out at 21 days. There was variation among the species in response to gold mine wastewater where jatropha and wild candlenut were less sensitive than castor bean and bead-tree plants (Fugure 4). Only at $75 \%$ of wastewater RWC of jatropha and wild candlenut decreased significantly $(\mathrm{p}<0.05)$. In castor bean and bead-tree plant, the significant $(\mathrm{p}<0.05)$

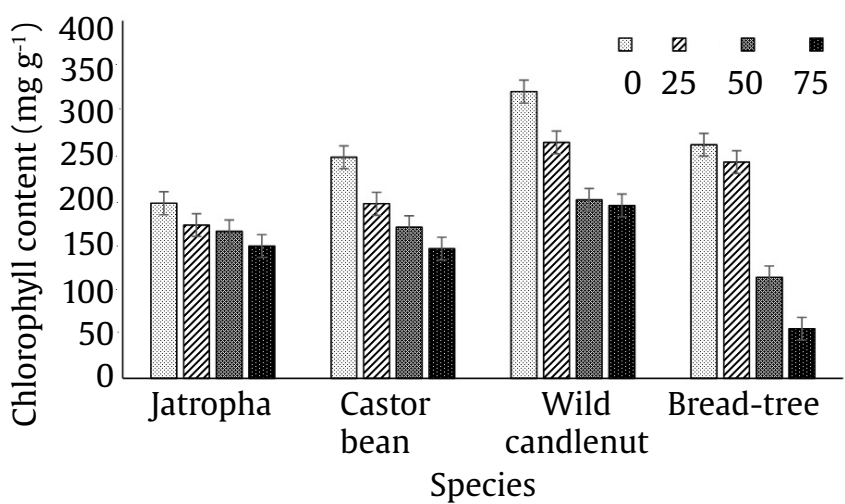

Figure 3. The verage content of Chlorophyll of the four plant species treated by gold mine wastewater of $0 \%, 25 \%, 50 \%$, and $75 \%$

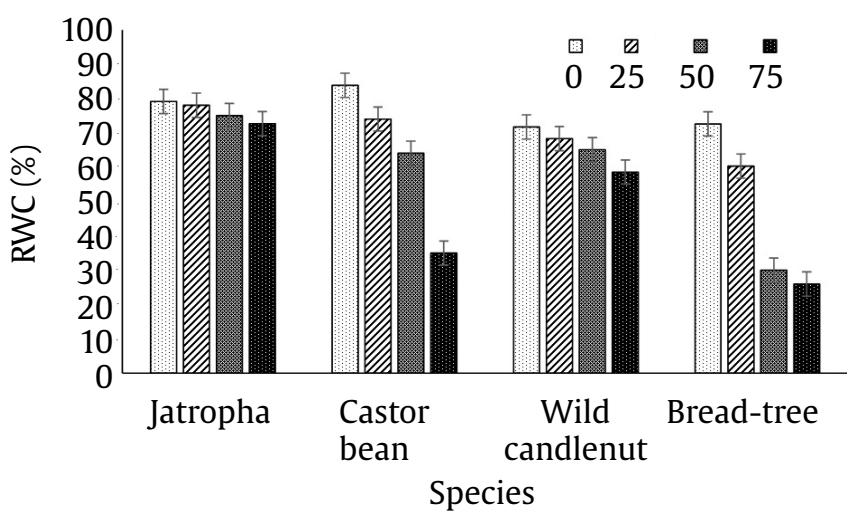

Figure 4. Relative water content of leaves (RWC) of four species treated with wastewater stress ranging from 0 to $75 \%$ in water culture reduction of RWC started evan at $25 \%$ of wastewater treatment (Figure 4). The reduction of RWC for castor bean and bead-tree plant was even more under the treatment of $50 \%$ and $75 \%$ of gold mine wastewater.

\subsubsection{Correlation Data of MDA, Chlorophyll, and Relative Water Contents}

Among the physiological parameters, there was a close correlation between leaf MDA content, chlorophyll content and relative water content. The increase of MDA content due to the increase of gold mine wastewater concentration was highly associated to the decrease of chlorophyll content as well as the decrease of relative water content indicated by high degree of coefficient correlation values $\left(R^{2}=0.9\right)$ as presented in Figure 5. Even though among the two graph had different slope, both of them (RWC and chlorophyll) had similar pattern in the relationship with the increase of MDA content.

\section{Discussion}

An analysis of gold mine wastewater collected from ore extraction showed that it contained very high cyanide $(\mathrm{CN})$, i.e. $34.59 \mathrm{mg} / \mathrm{l}$ (Table 1$)$, while other compounds including heavy metals such as $\mathrm{Pb}$ and $\mathrm{Hg}$ were relatively very low. This data suggested that cyanide is the most hazardous compound in gold mine wastewater that may influence living thing in the environment. The cyanide content in the wastewater far exceeded the maximum limit of $\mathrm{CN}$ that is still allowed to be disposed to the open environment (0.5 mg/l) (KLH 2004). For plants, high concentration of cyanide caused respiration

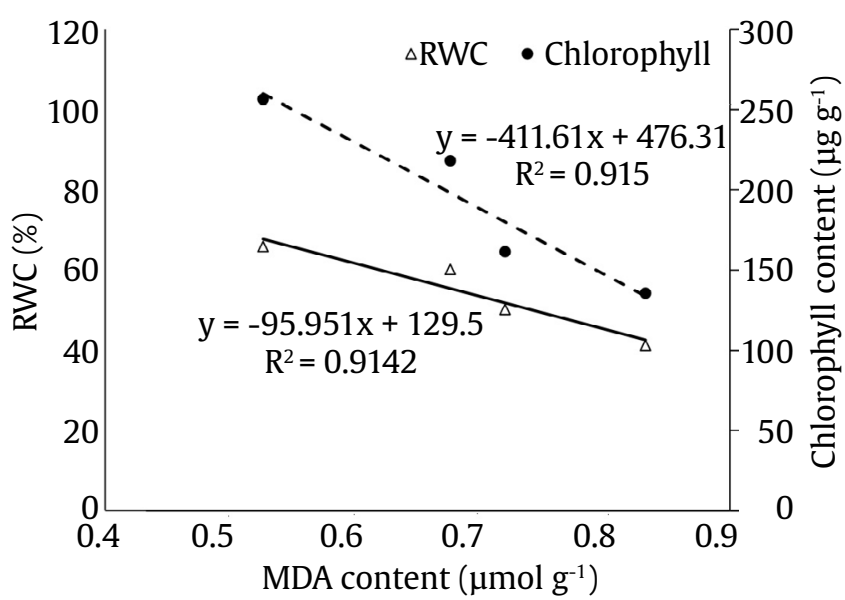

Figure 5. The graph of regression of MDA content and RWC and chlorophyll content of all species in response to gold mine wastewater 
inhibition, which reduced ATP production and other processes dependent on ATP such as growth and crop production (Eisler and Wiemeyer 2004). Plant tolerance to cyanide may involve substantial changes including morphology, anatomy, and physiology. Morphological parameters that were hampered due to stress of gold mine wastewater including: plant height, number of leaves, leaf area, roots and shoot dry weight, even though there was variation among the species (Tables 2, 3, 4, and Figure 1). The higher wastewater concentration caused significant decrease of plant height, leaf number, leaf area as well as dry weight of almost all species except $R$. trisperma. This clarified that high cyanide inhibited plant growth and development (Larsen et al. 2005; Blom et al. 2011).

The stress resulted from gold mine wastewater treatments may affect the anatomical structure of the leaves, even though it varied among the species. The decrease in leaf thickness, upper epidermis, palisade tissue, spongy tissue, and lower epidermis was as the response of the gold mine wastewater that was applied. The highest decrease in leaf thickness was found in Jatropha plant but not to the other plant species (Table 4). This result also verified what Hamim et al. (2017a) found previously that $R$. trisperma subjected to gold mine wastewater did not exhibit leaf anatomy alteration. Stevovic et al. (2010), specified that the thickness of leaves in stress conditions was lower than that of control. This was a form of plant response to stress.

The significant increase of malondialdehyde (MDA) content in response to gold mine wastewater (Figure 2) suggesting that the treatment using gold mine wastewater triggered the formation of Reactive Oxygen Species (ROS) and cause oxidative stress indicated by an increase in lipid peroxidation. MDA is an indicator to evaluate the level of cellular damage after stress treatment which is the main cytotoxic product of lipid peroxidation and has been widely used as an indicator of free radical production (Fu and Huang 2001; Hamim et al. 2017b). The increase of ROS may associated to the effect of higher cyanide content in the wastewater. Oracz et al. (2009) also notified that cyanide induced the formation of reactive oxygen species (ROS) and also triggers the production of hydrogen peroxide $\left(\mathrm{H}_{2} \mathrm{O}_{2}\right)$ in embryonic axes of sunflower (Helianthus annuus L.) by stimulating NADPH oxidase and inhibiting antioxidant enzymes for instance catalase.
There was a highly correlation between the increase of leaf MDA content and the substantial decrease of chlorophyll content due to gold mine wastewater treatment (Figures 2, 3, and 5). This strong correlation is an indicative that high content of cyanide in gold mine wastewater induced oxidative stress in the plant tissues which caused damage in lipid and protein as well as chlorophyll degradation (Blom et al. 2011). According to Prasad and Prasad (1990) chlorophyll a and b are very sensitive to oxidative stress, so that the reduction of chlorophyll a and/or b can also affect the reduction of total chlorophyll content. Decreased chlorophyll in leaves occurs due to inhibition of chlorophyll biosynthesis so that the enzyme aminolaevulinic acid (ALA) disrupts the formation of porphobilinogen (Singh 1995). Decreased leaf chlorophyll content can also be caused by chloroplast damage.

The lowest increase in MDA leaf content was found in wild candlenut and bead-tree plants (Figure 3a). For wild candlenut, this plant may have a defence mechanism to tolerate gold mine wastewater treatment, since all morphological parameters (Table 2, 3, 4, and Figure 1) showed that wild candlenut exhibited tolerance to gold mine wastewater which also associated to a fairly low level of damage represented by lower MDA level. This is consistent with Hamim et al. (2017a) who previously specified that wild candlenut has a resistance to gold mine liquid waste. It has been understood that some plant species has ability to tolerate cyanide by functioning the enzyme known as $\beta$-cyanoalanine synthase (CASase) to detoxify cyanide (Watanabe et al. 2008). Moreover O'Leary et al. (2014) even suggested the important of enzyme $\beta$-cyanoalanine nitrilase for cyanide detoxification in addition to CASase, that may have important role for cyanide phytoremediation. The process occurs where a mitochondrial $\beta$-cyanoalanine synthase (CAS) catalyses $\mathrm{CN}$ to cysteine to produce $\mathrm{H}_{2} \mathrm{~S}$ and $\beta$-cyanoalanine (Hatzfeld et al. 2000), then $\beta$-cyanoalanine is fully detoxified by $\beta$-cyanoalanine nitrilase to produce Asparagine or Aspartate (Piotrowski and Volmer 2006). On the other hand for bead-tree the lower MDA content was not associated to its tolerance characteristic because the plant was significantly retarded and finally dead due to gold mine wastewater. The lower MDA level in bead-tree may be due to the lower metabolic processes when the plant was almost dead. 
Gold mine wastewater also reduced relative water content (RWC) of the plant as the concentration of gold mine wastewater increased (Figure 4). RWC is also important indicator to determine the level of plant stress in response to abiotic stress, including heavy metal and xenobiotic stress (Sarwar et al. 2017). Plants that are stress have a low RWC value. Castor bean plants had the highest decrease in RWC value. This showed that gold mine wastewater caused plant water potential to decrease, so that the plants experienced symptoms such as drought.

Based on all morphological, anatomical, and physiological parameters, among four species that were observed, wild candlenut was the most resistant to gold mine wastewater. These plants survived in the highest concentration of gold mine wastewater until 21 days of the treatment.

\section{Acknowledgements}

This research was funded by the Directorate General of Higher Education, Ministry of Research, Technology and Higher Education Republic of Indonesia through Program of Penelitian Dasar Unggulan Perguruan Tinggi (PDUPT) with the Grant number of $129 /$ SP2H/PTNBH/DRPM/2018 on $1^{\text {st }}$ February 2018.

\section{References}

Barr HD, Weatherley PE. 1962. A re-examination of the relative turgidity techniques for estimating water deficits in leaves. Biol Sci 15:413-428.

Blom D et al. 2011. Volatile mediated killing of Arabidopsis thaliana by bacteria is mainly due to hydrogen cyanide. Appl Environ Microb 77:1000-1008.

Chaney Ret al. 1995. Potential use of metal hyperaccumulators. Mining Environ Manag 3:9-11.

Ebbs S. 2004. Biological degradation of cyanide compounds. Curr Opin Biotechnol 15:231-236.

Epstein E. 1972. Mineral Nutrition of Plants: Principles and Perspectives. New York: Wiley Eastern Ltd.

Eisler R, Wiemeyer SN. 2004. Cyanide hazards to plants and animals from gold mining and related water issues. Rev Environ Contam Toxicol 183:21-54.

Feng NX et al. 2017. Efficient phytoremediation of organic contaminants in soils using plant-endophyte partnerships. Sci Total Envir 583:352-368.

Fu J, Huang B. 2001. Involvement of antioxidants and lipid peroxidation in the adaptation of two cool-seasion grasses to localized drought stress. Environ Exper Bot 45:105-114.

Hamim H et al. 2017a. Morpho-physiological changes of biodiesel producer plants Reutealis trisperma [Blanco] in response to gold-mining wastewater. Pak J Biol Sci 20:423-435.
Hamim H et al. 2017b. Oxidative stress and photosynthesis reduction of cultivated (Glycine max 1.) and wild soybean (G. tomentella L.) exposed to drought and paraquat. Asian J Plant Sci 16:65-77.

Hatzfeld $\mathrm{Y}$ et al. 2000. B-Cyanoalanine synthase is a mitochondrial cysteine synthase-like protein in spinach and Arabidopsis. Plant Physiol 123:1163-1171.

Hidayati N et al. 2009. Mercury and cyanide contaminations in gold mine environment and possible solution of cleaning up by using phytoextraction. Hayati J Biosci $16: 88-94$.

Hilmi M et al. 2018. Growth, histochemical and physiological responses of non-edible oil producing plant (Reutealis trisperma) to gold mine tailings. Biodiversitas 19:12941302.

Hodges DM et al. 1999. Improving the thiobarbituric acid reactive substances assay for estimating lipid peroxidation in plant tissue containing anthocyanin and other interfering compounds. Planta 207:604-611.

[KLH] Indonesian Ministry of Environment. 2004. The Decree of The State Minister of Environment, Republic of Indonesia. No: 202 Year 2004, Regarding The Waste Water Quality Standards for Businesses and/or Mining Activities for Gold and or Copper Ore. Jakarta. Indonesia.

Khamis MH et al. 2014. Phytoextraction potential of cadmium and lead contamination using Melia azedarach and Populus alba seedlings. Afr J Biotechnol 13:4726-4732.

Krisnayanti BD, Anderson C. 2014. Gold phytomining: a new idea for environmental sustainability in Indonesia. Indon J Geosci 1:1-7.

Larsen M et al. 2005. Uptake, metabolism, accumulation and toxicity of cyanide in willow trees. Environ Sci Technol 39:2135-2142.

Lichtenthaler HK. 1987. Chlorophylls and carotenoids: pigments of photosynthetic biomembranes. Methods in Enzymol 148:350-382.

O`Leary B et al. 2014. Increased $\beta$-cyanoalanine nitrilase activity improves cyanide tolerance and assimilation in Arabidopsis. Molec Plant 7:231-243.

Oracz K et al. 2009. The mechanisms involved in seed dormancy alleviation by hydrogen cyanide unravel the role of reactive oxygen species as key factors of cellular signaling during germination. Plant Physiol 150:494-505.

Piotrowski M, Volmer JJ. 2006. Cyanide metabolism in higher plants: cyanoalanine hydratase is a NIT4 homolog. Plant Mol Biol 61:111-122.

Pranowo D et al. 2015. The potency of candlenut (Reuteulis trisperma (Blanco) Air Shaw) development in degraded land. Jurnal Pertanian 14:87-101.

Prasad DDK, Prasad ARK. 1990. Porphyrin metabolism in lead and mercury treated Bajra (Pennisetum typhoideum) seedlings. J Biosci 15:271-292.

Romeiro S et al. 2006. Lead uptake and tolerance of Ricinus communis L. Braz J Plant Physiol 18:483-489.

Quinet $M$ et al. 2012. Combined transcriptomic and physiological approaches reveal strong differences between short-and long-term responses of rice (Oryza sativa) to iron toxicity. Plant Cell Environ. 35:1837-1859

Rodríguez E et al. 2009. Effect of mercury and gold on growth, nutrient uptake, and anatomical changes in Chilopsis linearis. Environ Exp Bot 65:253-262.

Sarwar N et al. 2017. Phytoremediation strategies for soils contaminated with heavy metals: Modifications and future perspectives. Chemosphere 171:710-721. 
Setyaningsih L et al. 2018a. Jabon (Anthocephalus cadamba Roxb) potency for remediating lead $(\mathrm{Pb})$ toxicity under nutrient culture condition. Biotropia 25:64-71.

Setyaningsih L et al. 2018b. Growth of typha grass (Typha angustifolia) on gold-mine tailings with application of arbuscular mycorrhiza fungi. BIODIVERSITAS 19:454459.

Singh VP. 1995. Toxic metal cadmium: phytotoxicity and tolerance in plants. In: Trivedy RK (Eds.). Adv Environ Sci Technol. New Delhi: Ashish Publication House. pp. 225-256.
Stevovic Set al. 2010. Environmental impact on morphological and anatomical structure of Tansy. African Journal of Biotechnology 9:2413-2421.

Towill LE et al. 1978. Reviews of the Environmental Effects of Pollutants: V. Cyanide. 600/1-78-027. Washington: USEPA.

Watanabe M et al. 2008. Physiological roles of the betasubstituted alanine synthase gene family in Arabidopsis. Plant Physiol 146:310-20. 